\title{
TRANSITIONS TOWARDS OPERATIONAL SPACE-BASED OCEAN OBSERVATIONS: FROM SINGLE RESEARCH MISSIONS INTO SERIES AND CONSTELLATIONS
}

\author{
Hans Bonekamp ${ }^{(1)}$, Francois Parisot ${ }^{(1)}$, Stan Wilson $^{(2)}$, Laury Miller ${ }^{(2)}$, Craig Donlon ${ }^{(3)}$, Mark Drinkwater ${ }^{(3)}$, Eric \\ Lindstrom $^{(4)}$, Lee Fu ${ }^{(5)}$, Eric Thouvenot ${ }^{(6)}$, Juliette Lambin ${ }^{(6)}$, Keizo Nakagawa ${ }^{(7)}$, B.S. Gohil ${ }^{(8)}$, Mingsen Lin ${ }^{(9)}$, \\ James Yoder $^{(10)}$, Pierre-Yves le Traon ${ }^{(11)}$, Gregg Jacobs ${ }^{(12)}$ \\ (I) EUMETSAT, EUMETSAT-Allee 1, 64295 Darmstadt, Germany, \\ Email: hans.bonekamp@eumetsat.int, francois.parisot@eumetsat.int \\ ${ }^{(2)}$ NOAA/NESDIS, 1335 East West Highway, Silver Spring, MD 20910, U.S.A., \\ Email: stan.wilson@noaa.gov, laury.miller@noaa.gov \\ ${ }^{(3)}$ ESA/ESTEC, Keplerlaan 1, NL-2201 AZ Noordwijk, The Netherlands, \\ Email: craig.donlon@esa.int, mark.drinkwater@esa.int, \\ (4) NASA HQ, MS 3F71, 300 E St. SW, Washington, DC 20546, U.S.A., \\ Email: eric.j.lindstrom@nasa.gov \\ ${ }^{(5)}$ NASA JPL, MS 300-323, 4800 Oak Grove Drive, Pasadena, CA 91109, U.S.A., \\ Email: llf@jpl.nasa.gov \\ ${ }^{(6)}$ CNES/TSC, 18 avenue Edouard Belin, 31401 France, \\ Email: eric.thouvenot@cnes.fr, juliette.lambin@cnes.fr \\ ${ }^{(7)}$ SAMD, JAXA, 2-1-1, Sengen, Tsukuba-shi, Ibaraki, Japan, \\ Email: keizo.nakagawa@jaxa.jp \\ ${ }^{(8)}$ Meteorology \& Oceanography Group, ISRO, Bopal Campus, Ahmedabad-380015, India, \\ Email: bsgohil@sac.isro.gov.in, \\ ${ }^{(9)}$ NMEFC/SOA, 8 Dahuisi Road, Haidian District, Beijing 100081, China, \\ Email:mslin@mail.nsoas.gov.cn \\ ${ }^{(10)}$ Woods Hole Oceanographic Institution, Woods Hole, MA 02540 USA, \\ Email: jyoder@whoi.edu \\ ${ }^{(11)}$ IFREMER Centre de Brest B.P. 70 29280, Plouzané France, \\ Email: pierre.yves.le.traon@ifremer.fr \\ ${ }^{(12)}$ NRL 7320, Stennis Space Center, MS 39529, U.S.A., \\ Email: gregg.jacobs@nrlssc.navy.mil
}

\begin{abstract}
This paper discusses aspects of the development of operational satellite programmes for oceanography. In particular, it explains transitioning of key ocean missions from research to a sustained operational context. Successes over the last decade are highlighted as well as challenges for the decades to come.
\end{abstract}

\section{INTRODUCTION}

Most experimental space missions and technologies are not solely developed for the sake of their technological and scientific challenge, but to realise a long-term return on the research and development investments. The missions are required to demonstrate their value for direct operational use or in assimilation with operational models. When successful in these aspects, their operational usefulness may become the strongest driver behind follow-on missions and programmatically the mission, or rather the sequence of missions, has to make a transition to become a component in a wider operational structure and planning. This transition brings about new challenges and constraints on the mission programmatic procurements, the mission operations and the exploitation of the data.

As presented in Tab. 1, we can identify major differences between a typical operational mission and typical research mission. Existing or planned future operational and research missions do however not necessarily follow this idealised picture. For example, AATSR (Advanced Along-Track Scanning Radiomete) mission on ENVISAT (Environmental Satellite), QuikSCAT (Quick Scatterometer Satellite) or Jason-1 are all research missions, which are or have been fully exploited for operational purposes. In addition, there are several examples of experimental missions flying on operational platforms.

Transitioning space missions from the research into an operational context one is not a straightforward task or process. Program development and program scheduling have to deal with major issues like, affordability, variability in actual mission life times, political context, and evolving and sometimes contradicting user requirements. These factors tend to make the distinction 


\begin{tabular}{|l|l|l|}
\hline & \multicolumn{1}{|c|}{ Operational Mission } & \multicolumn{1}{c|}{ Research Mission } \\
\hline Key Drivers & Social benefits, user and service requirements & $\begin{array}{l}\text { Scientific objectives, technological challenges and } \\
\text { social benefits. }\end{array}$ \\
\hline Funding & $\begin{array}{l}\text { Operational agencies and operational } \\
\text { institutions (NOAA, EUMETSAT...) }\end{array}$ & Research \& Development agencies (NASA, ESA...) \\
\hline Key data users & Forecasters, advisory entities & Scientists, research agencies and laboratories \\
\hline Availability & Guaranteed, Monitored & Best Effort \\
\hline Dissemination & Operational Networks & $\begin{array}{l}\text { FTP and internet, to research agencies, scientists and } \\
\text { Principal Investigator consortia. }\end{array}$ \\
\hline Support & Pro-active, 24/7 & Pro active in many cases but rarely 24/7 \\
\hline Sustainability & Continuous & Incremental \\
\hline
\end{tabular}

Table 1. Major differences between an operational and a research mission.

between operational and research missions less relevant in a reality also driven by pragmatism.

At the OceanObs Conference in St Raphael, 1999, it was already noted that the research and development space agencies made great progress in setting up a space-born observing capability for the global oceans and, incrementally, the transition towards an enhanced operational space component of the Global Ocean Observing System (GOOS) had already started, see e.g., Ratier [1]. Over the last decade, the fast development of operational oceanography (Ocean Weather Prediction) guided by the Global Ocean Data Assimilation Experiment (GODAE) [2], and related projects such as done by the Group for High-Resolution SST (Sea Surface Temperature) (GHRSST) [3]), formed a strong impetus to further transition ocean remote sensing missions into sustained sequences of operational missions. Later in this paper, we will point out several mission examples of this process. In parallel, and similar to practices in the Numerical Weather Prediction (NWP) community supporting operational model and data services for decades, oceanographic user consultancy and data usage activities were organised to ensure that the user requirements critical for operations were reported to guide space agency program development.

Additional stimuli for transition into operations and sustainability came from the NWP community, enhancing its services in marine meteorology and setting up operating coupled ocean-atmosphere models for the longer term and seasonal weather predictions.
The Global Climate Observing System (GCOS) emphasised furthermore the increased need of long-term access to data and information of the ocean component of the earth's climate system. Climate applications express in particular a challenging demand for (inter-) calibration, stability characterisation, and reprocessing of the mission data, which include all operational and research satellite missions. This implies continued active involvement of research and development oriented space agencies also to re-assess their ongoing or completed mission. An example in this respect is the new ESA (European Space Agency) Climate Change Initiative that will re-process ESA satellite archives together with other satellite data in support of GCOS Essential Climate Variable requirements [4].

Table 2 lists the key OceanObs 2009 Community White Papers (CWP's) which address in full detail the operational and climate applications and their requirements on the observational infrastructure. From a high-level global perspective, these requirements and their development activities fall under the first version of the Global Earth Observation System of Systems (GEOSS) that will provide decision-support tools to very wide variety of users (see for more details, http://earthobservations.org/geoss.shtml). It has to be strongly emphasised, as expressed among others in these CWP's, that the full potential of the space-based observing capability can only be realised in a synergetic context of an integrated system including the in-situ elements. 


\begin{tabular}{|c|c|c|}
\hline $\begin{array}{l}\text { Operational } \\
\text { Applications }\end{array}$ & $\begin{array}{c}\text { Status of } \\
\text { application } \\
\text { s }\end{array}$ & $\begin{array}{l}\text { Community White } \\
\text { or Plenary Paper }\end{array}$ \\
\hline $\begin{array}{l}\text { Operational } \\
\text { Oceanography }\end{array}$ & $\begin{array}{l}\text { Emerging, } \\
\text { maturing }\end{array}$ & $\begin{array}{l}\text { Godae OceanView } \\
\text { [5] } \\
\text { Bahurel et al. [6] }\end{array}$ \\
\hline $\begin{array}{l}\text { Numerical } \\
\text { Weather } \\
\text { Prediction, } \\
\text { Seasonal } \\
\text { forecasting and } \\
\text { Decadal Forecasts }\end{array}$ & $\begin{array}{l}\text { Expanding, } \\
\text { enhancing }\end{array}$ & $\begin{array}{l}\text { Brassington et al. } \\
\text { [7] } \\
\text { Eyre et al. [8] } \\
\text { Balmaseda et al. [9] } \\
\text { Hurrell et al. (10) }\end{array}$ \\
\hline $\begin{array}{l}\text { Climate ocean } \\
\text { state estimation, } \\
\text { surface flux } \\
\text { estimation, climate } \\
\text { monitoring. }\end{array}$ & $\begin{array}{l}\text { Emerging, } \\
\text { critical }\end{array}$ & $\begin{array}{l}\text { Fairall et al. [11] } \\
\text { Gulev et al. [12] } \\
\text { Lee et al. [13] } \\
\text { Nerem et al. [14] }\end{array}$ \\
\hline
\end{tabular}

Table 2. OceanObs 2009 Community White Papers addressing requirements for the operational applications in oceanography.

The strong momentum gained through the increased operational demand for ocean missions does not imply an easy agreement among agencies and institutions and straightforward transitioning paths. The procurement of series of operational missions demands special care in the early planning and development phases. In parallel, forming a conflicting interest, space agencies are continuously requested to support the development of new observation techniques for both existing and new geophysical variables, In fact, key issues as already expressed during OceanObs 1999 remain in the core of space agency program development today and may have even become more complex with the various concurrent application goals set. Particular issues to quote from Ratier's [1] OceanObs 1999 contribution are:

1) Operational Oceanography may well fall between two stools, if development and operational agencies do not balance their respective investments, or if they compete for the same resources or fail to agree on appropriate transition scenarios.

2) Planning will also continue to require international co-operation and co-ordination, e.g. in the framework of the Integrated Global Observing Strategy promoted by CEOS [Committee on Earth Observation Satellites], in order to avoid major duplication of efforts, whilst preserving the minimum redundancy required by operational services.

The implementation of the Integrated Global Observing Strategy has been transferred into the implementation of the GEOSS as coordinated by the Group for Earth Observations (GEO).

\begin{tabular}{|l|l|}
\hline Oceanographic Variable & Community White Paper \\
\hline $\begin{array}{l}\text { Sea Surface } \\
\text { Temperature }\end{array}$ & Donlon et al. [15] \\
\hline $\begin{array}{l}\text { Ocean Surface } \\
\text { Topography }\end{array}$ & Wilson et al. [16] \\
\hline Ocean Vector Winds & Bourassa et al. [17] \\
\hline Ocean Colour & Yoder et al. [18] \\
\hline Ocean Salinity & Lagerloef et al. [19] \\
\hline Sea Ice Storm & Swail et al. 2009 [21] \\
\hline $\begin{array}{l}\text { Sea State and Surge } \\
\text { Surget al. [20] }\end{array}$ \\
\hline
\end{tabular}

Table 3. OceanObs 2009 Community White Papers addressing space based operational observing capabilities for key oceanographic variables.

In this paper, we assess the progress of transition towards sustainable and permanent operational satellite systems for key oceanographic variables that can be observed from space. Clearly, it is not possible to address all the individual mission successes, achievements and complications in detail. Tab. 3 refers to several underlying OceanObs 2009 Community White Papers (CWP) and Plenary Papers (PP) discussing in detail mission developments and requirements from the perspective of the communities featuring these key observables. Here, we take an overall programmatic and a life cycle management perspective on mission procurement and development to highlight advances in subsequent stages of innovation (see Sect. 2).

At the final GODAE symposium in Nice 2008, Wilson et al. [22] already recognised that for key variables the progress was considerable over the last decade. But there are also challenges to address. By comparing the communities and processing chains of the key observables not only in terms of numbered and scheduled existing, approved, or proposed missions, but also in terms of international orientation and integration, cross mission optimisation, maturity of data product design, awareness, and dissemination, the parallels between and differences among these key observables may help to conclude on the efficacy of applied transition approaches and may help to make sensible recommendations for the future. In any case, from an operational perspective it is undesirable if a specific key variable would fall dramatically behind the others, because the applications need the constraining effect of the physical relations between these key variables. 
From the climate perspective, the key oceanographic variables are listed as Essential Climate Variables (ECV's) in the Global Climate Observing System Implementation Plan issued by the World Meteorological Organization [4]. This implementation plan imposes guidelines or the procurement of the satellite missions and product data setting the scene for further co-operation among the various communities and institutions.

Finally, it is important to mention that official positions of the engaged space agencies or institutions are not necessarily expressed in this paper. The objective is to indicate where a broader consensus within communities has been found or can be explored in the near future.

\section{ACTUAL TRANSITIONS OF OCEAN MISSIONS}

Summarizing and re-sorting the input from the OceanObs 2009 CWP's and PP's as referenced in Tab. 3 we can re-list the identified ocean missions or spaceborn instruments for the key oceanographic variables in three subsequent phases of innovation. The result is provided in Tab. 4. For details on the missions or instruments indicated by the various acronyms, the reader is referred to the CEOS handbook [23], http://www.eohandbook.com.

The three subsequent phases of innovation (columns of Tab. 4) are: 1) Development and demonstration, 2) Sustainability and continuation, 3) Demonstration of new capabilities. The first phase could perhaps also be called first capability development and has been a major topic at OceanObs 1999. It defines what would work and what would not or only conditionally or partially. Currently at the OceanObs 2009 Conference, the second phase is in the centre of attention. New capabilities are addressed in the Plenary Papers by Lindstrom et al. [24] and Drinkwater et al. [25]. Ideally, in terms of funding and close to what is often the practice for atmospheric missions, the research and development agencies after having funded the first phase would step back to leave the responsibility for the second phase to the operational agencies to concentrate on the third phase, which is demonstration of new capabilities, completing the circle of product innovation. It has to be remarked that the development of new capabilities like SWOT (Surface Water and Ocean Topography Mission) and XOVWM (Extended Ocean Vector Winds Mission) maybe become very expensive compared to alternative constellation approaches. To explore the benefits of various sharing communities as is currently ongoing will help, but it is doubtful whether the impetus for such missions can come solely from user needs. Dedication from the research agencies is asked for.

As said in the introduction sustained observations with demonstrated technology are the requirement for operations and climate assessment. The endeavour involves all nations. Besides a continuation of research missions, we clearly identify in Tab. 4 missions from a broad spectrum of nations and some type of mission have become a commodity. This globalisation has definitely advantages in terms of meeting temporal and spatial requirements provided that timely open access to data is guaranteed and provided that the missions are complementary in terms of phasing.

The key question of this section translates to: How well are we today entered the second column of Tab. 4? How far did we transition into operational satellite oceanography? We discuss the progress for the key variables individually.

\subsection{Sea Surface Temperature}

For SST (Sea Surface Temperature) the picture is bright. Series of missions are approved or planned for, funded or at least supported by operational agencies in both geostationary orbits and polar orbiting satellites. Operational SST observing systems have been dominantly justified by the meteorological requirements, but these are aligned with those of the oceanographic community. Here, we focus on the Low Earth Orbiting missions. To mention are the AVHRR (Advanced Very High Resolution Radiometer) missions in the context of the (Initial) Joint Polar System, the cooperation between NOAA (National Oceanic and Atmospheric Administration) and EUMETSAT (European Organisation for the Exploitation of Meteorological Satellites) for the operational NPP (Polar Orbiting Environmental Satellite System Preparatory Project), NPOESS (Polar Orbiting Environmental Satellite System), EPS (EUMETSAT Polar System), and Post EPS programs. The accurate ATSR (Along Track Scanning Radiometer) and AATSR missions find their continuation in SLSTR (Sea and Land Surface Temperature Radiometer) missions on Sentinel 3 series. The development and funding of Sentinel-3 is lead by ESA in the context of the GMES (Global Monitoring for Environment and Security) but it is agreed that EUMETSAT will operate the series. Donlon et al [15] expressed also the need to secure the continuation of microwave SST retrievals (e.g. GCOMW (Global Change Observation Mission-Water) series) and to consider flying an SLSTR instrument in an asynchronous orbit to act as a long-term calibration reference for other SST sensors.

\subsection{Ocean Dynamic Topography}

For dynamic surface topography, the picture is also bright. The Jason series is prolonged with constituting funding from the operational agencies NOAA and EUMETSAT for the Jason-3 mission. Moreover, 


\begin{tabular}{|c|c|c|c|}
\hline & Development \& Demonstation & $\begin{array}{l}\text { Sustainability and continuation } \\
\text { (Series of satellites) }\end{array}$ & $\begin{array}{l}\text { Demonstration of new } \\
\text { capabilities }\end{array}$ \\
\hline $\begin{array}{l}\text { Sea Surface } \\
\text { Temperature } \\
\text { (1) }\end{array}$ & $\begin{array}{l}\text { METEOSAT, GOES } \\
\text { AVHRR (TIROS), AVHRR (NOAA- } \\
\text { 7.) } \\
\text { ATSR (ERS), AATSR (ENVISAT) } \\
\text { MODIS } \\
\text { AMSR-E } \\
\text { TRMM TMI }\end{array}$ & $\begin{array}{l}\text { MSG SEVIRI, GOES imager } \\
\text { AVHRR/3 (METOP A, B, C) AVHRR /3 (NOAA, 15, } \\
\text { 16, 17, 18, N') } \\
\text { SLTSR (Sentinel 3A, 3B, ...) } \\
\text { VIIRS (NPP, NPOESS-C1, C2, C3) } \\
\text { AMSR-2 (GCOM-W1, W2, W3) }\end{array}$ & ESA MicroWat concept \\
\hline $\begin{array}{l}\text { Ocean } \\
\text { Surface } \\
\text { Topography }\end{array}$ & $\begin{array}{l}\text { TOPEX/Poseidon, Jason-1 } \\
\text { RA (ERS), RA2 (ENVISAT) } \\
\text { GEOSAT, GFO }\end{array}$ & $\begin{array}{l}\text { Jason-2, Jason-3, Jason-CS } \\
\text { SRAL (Sentinel 3A, 3B, ...) } \\
\text { SARAL/AltiKa } \\
\text { GFO2 } \\
\text { HY 2A, 2B, 2C, 2D }\end{array}$ & $\begin{array}{l}\text { SWOT } \\
\text { IRAC }\end{array}$ \\
\hline $\begin{array}{l}\text { Ocean } \\
\text { Vector } \\
\text { Winds }\end{array}$ & $\begin{array}{l}\text { SeaWinds (QuikSCAT, Adeos) } \\
\text { ERS }\end{array}$ & $\begin{array}{l}\text { Dual Frequency Scatterometer 1, } 2 \text { (GCOM-W2, W3) } \\
\text { ASCAT (METOP A, B, C), scatterometer on POST- } \\
\text { EPS } \\
\text { Scatterometer on OCEANSAT-2, } 3 \\
\text { Scaterometer on HY-2A } \\
\text { Scatterometer on Meteor } 3\end{array}$ & $\begin{array}{l}\text { XOVWM } \\
\text { CFOSAT } \\
\text { ESA MicroWat concept }\end{array}$ \\
\hline $\begin{array}{l}\text { Ocean } \\
\text { Colour }\end{array}$ & $\begin{array}{l}\text { CZCS, SeaWIFS MODIS } \\
\text { MERIS (ENVISAT) } \\
\text { OCTS, GLI } \\
\text { COCTS (HY1) }\end{array}$ & $\begin{array}{l}\text { VIIRS (NPP, NPOESS-C1,C2,C3) } \\
\text { OLCI (Sentinel 3A, 3B, ...) } \\
\text { SGLI on GCOM-C } \\
\text { OCS on OCEANSAT-2, } 3\end{array}$ & $\begin{array}{l}\text { COMS1-GOCI } \\
\text { ACE } \\
\text { GEO-CAPE } \\
\text { Geo-Oculus }\end{array}$ \\
\hline $\begin{array}{l}\text { Ocean } \\
\text { Salinity }\end{array}$ & $\begin{array}{l}\text { SMOS } \\
\text { Aquarius }\end{array}$ & & $\begin{array}{l}\text { SMOS-NEXT } \\
\text { SMAP }\end{array}$ \\
\hline Sea Ice & $\begin{array}{l}\text { SSMR SSM/I } \\
\text { ERS/ENVISAT SAR } \\
\text { RADARSAT } \\
\text { PALSAR } \\
\text { Radiometers, see also Sea Surface Tem } \\
\text { Altimeters, see also Ocean Surface Top } \\
\text { Scattterometers, see also Ocean Surfac }\end{array}$ & $\begin{array}{l}\text { MIS (NPOESS-C1, C2) } \\
\text { Sentinel-1A, ... } \\
\text { RADARSAT2 }\end{array}$ & ICESAT (-2), CryoSat-2 \\
\hline
\end{tabular}

Table 4. Ocean missions or space-borne instruments for key oceanographic variables placed in subsequent phases of development and innovation. The mentioned missions or instruments are operational, approved or proposed. 
concept definition and agency cooperation have started for a series of missions beyond Jason-3. In the context of this paper, it is important to note that Jason-2 constitutes a pivoting mission in the transition. The Jason-2 program encompasses both two research (NASA, CNES (Centre National d'Études Spatiales)) and two operational agencies (NOAA and EUMETSAT) to ensure on the one hand an operational procurement and on the other hand a continuation of the research involved. After the Jason-3 mission, an orbit optimisation is foreseen to ensure that the future constellation (see also Sect. 3) of nadir altimeters is the best compromise from a multi-mission perspective. Equally, important, series of Chinese and Indian altimeter missions have been approved and agency cooperation agreements are updated to allow global utilisation.

\subsection{Ocean Surface Winds}

For Ocean wind, the situation is bright in the sense that operational and approved continuation of $\mathrm{C}$-band scattermetry is provided by ASCAT (Advanced Scatterometer) on METOP (Meteorological Operational Satellite) platform A, B and C and a follow-on scatterometer mission has the highest priority the PostEPS framework. ISRO has successfully launched its Oceansat-2 satellite on 23 September 2009, carrying a $\mathrm{Ku}$ band pencil beam scatterometer. Oceansat-3 will follow. Chinese and Russian scatterometer missions are planned for the near future, and also passive techniques for surface wind information are continued, (not listed in Tab. 4) Passive microwave imagers and altimeters provide information on wind speed only.

The very successful Seawinds mission on QuikSCAT, formed the the backbone mission for the Ocean Surface winds community over the last decade. It unfortunately stopped its operational services in November 2009. As its follow-up, the US and Japan are proposing a combined $\mathrm{Ku}$ and $\mathrm{C}$ band scatterometer mission to fly on the GCOM-W series.

\subsection{Ocean Colour}

Since the 1990s, a variety of missions (OCTS (Ocean Color Temperature Scanner), SEAWIFS (Sea-viewing Wide Field-of-view Sensor), MODIS (Moderate Resolution Imaging Spectroradiometer), MERIS (MEdium Resolution Imaging Spectrometer). COCTS (Chinese Ocean Colour and Temperature Scanner), GLI (Global Imager)) have demonstrated that geophysical variables such as chlorophyll could be inferred from top of the atmosphere radiances with the needed stability and continuity. The data of these missions already have found their way in operational use, hence 'Ocean Colour' is moving into be an essential part of operational space oceanography. These missions have their follow-on on ocean-dedicated series of satellites such as the OLCI (Ocean and Land Color Instrument) on Sentinel-3, or OCS (Ocean colour scanner) on OceanSat.

\subsection{Ocean Surface Salinity}

Sea surface salinity is emerging as a new research product from satellite measurements of ocean brightness temperature at L-band (microwave) frequencies. As indicated by Tab. 4, Ocean Surface Salinity is not really in the phase of sustainability or continuation. Missions like SMOS (Soil Moisture and Ocean Salinity) and Aquarius still have to demonstrate that they meet the set expectations and successful application model data integrations have to be shown. ESA launched SMOS on 2 November 2009 to demonstrate an interferometric measurement of the sea surface salinity. NASA/CONAE (Comisión Nacional de Actividades Espaciales- Argentine Space Agency) will fly Aquarius/SAC-D (Satelite de Aplicaciones CientificasSatellite for Scientific Applications Satellite for Scientific Applications) in 2010 to demonstrate measurement of the sea surface salinity ECV.

\subsection{Sea Ice}

Sea ice Observation follows to a large extent the developments of the missions dedicated to the other observables. Besides AMSR-E (Advanced Microwave Scanning Radiometer for EOS (Earth Observing System)), the SMMR (Scanning Multichannel Microwave Radiometer) and the SSM/I (Special Sensor Microwave/Imager) missions have formed the basis of sea ice concentration monitoring over last decades (see Breivik et al. [20]). As for SST, it is importance to secure the operational passive microwave imaging to continue the long global sea ice data record for climate monitoring. Sea ice drift applications depend strongly on the availability of scatterometer data, which is in first instance determined by the needs for ocean vector winds as discussed in Sect. 2.3. Likewise, sea ice thickness depends on altimetry, see Sect. 2.2. New capabilities for Sea Ice Thickness are underway with, e.g., the ICESAT (Ice, Cloud,and land Elevation Satellite) and CryoSat-2 (Cryosphere Satellite) missions. The community expressed that the access to SAR data for operational sea ice monitoring should be further developed and improved over the next decade. With, for example, the Sentinel-1 mission as part of the GMES space segment this is in progress.

\section{INTERNATIONAL COOPERATION AND COORDINATION}

As expressed in the second quote from Ratier [1] (see Sect. 1) transition into sustainability and continuation requires an orientation towards international cooperation and coordination. These can take place either by formulating joint programs or more modestly 
on a best effort basis recognizing that there may be constraints on how wide the scope for coordination and cooperation can be. One can observe an enhanced intercontinental cooperation and coordination. One can also observe different type of cooperation and coordination. For example, one can break them down in programmatic, scientific, or operational. Here, we here distinguish: 1) Constellation thinking (either or not in the framework of CEOS), 2) creating International Science Teams, 3) Operational Cooperation.

Firstly, in the last years in the context of CEOS contributions for setting up the GEOSS, several virtual constellations are set up to enhance programmatic co ordination. CEOS virtual constellations from basis for a process aimed at addressing inter-comparability of different missions, integrated usage, data format and distribution harmonisation. Constellation thinking follows naturally from needs for continuation and operational robustness based on proven technology.

Secondly, with a much longer record of accomplishment, ocean missions both research and operational, are supported by science teams which are naturally joining up in the general international orientation of science. Thirdly, especially when cooperation agreements between agencies are in place, operational work may be shared in terms of facilities, resources and alignment of back-up processing. This kind of cooperation further enhances the robustness of the operational observing system. Key examples are the EUMETSAT-NOAA Initial Joint Polar System cooperation (IJPS) and the Jason-2 mission.

It has to be highlighted that there is a lot of interplay between the three mentioned kinds of cooperation: In terms of people, as scientist may function in operational ground segments, application institutions, or as agency program officers, but also in terms of tasks, as programmatic contexts identify key operational or scientific issues to be addressed.

Along these lines we again assess the key variables of ocean missions based, e.g., on the detailed input provided by OceanObs 2009 CWP's an PP's as listed in Tab. 3. The outcome is summarised in Tab. 5 .

\begin{tabular}{|l|l|l|l|}
\hline & (CEOS) Constellation & International Science Team & Operational Cooperation \\
\hline $\begin{array}{l}\text { Sea Surface } \\
\text { Temperature }\end{array}$ & $\begin{array}{l}\text { Group for High resolution } \\
\text { Sea Surface Temperature } \\
\text { (GHRSST) } \\
\text { (Coordination GHRSST- } \\
\text { CEOS now emerging.) }\end{array}$ & GHRSST & $\begin{array}{l}\text { GHRSST } \\
\text { Mature (including EUMETSAT, } \\
\text { NOAA, ESA, NASA, EU-GMES, } \\
\text { JAXA with emerging contributions } \\
\text { from Korea, China and Russia) }\end{array}$ \\
\hline $\begin{array}{l}\text { Ocean Surface } \\
\text { Topography }\end{array}$ & $\begin{array}{l}\text { Ocean Surface Topography } \\
\text { Virtual constellation (OST } \\
\text { VC) }\end{array}$ & $\begin{array}{l}\text { Ocean Surface Topography } \\
\text { Science Team (OST ST) }\end{array}$ & Mature. \\
\hline $\begin{array}{l}\text { Ocean Vector } \\
\text { Winds }\end{array}$ & $\begin{array}{l}\text { Ocean Vector Wind Virtual } \\
\text { Constellation } \\
\text { (OVW VC) }\end{array}$ & $\begin{array}{l}\text { International OceanVector } \\
\text { Wind Science Team (formed in } \\
2010) .\end{array}$ & $\begin{array}{l}\text { In place as part of the Initial Joint } \\
\text { Polar System }\end{array}$ \\
\hline Ocean Colour & OCR VC (IOCCG) & IOCCG & Under development \\
\hline Ocean Salinity & Under discussion & - & $\begin{array}{l}\text { (PolarView, } \\
\text { CliC) }\end{array}$ \\
\hline Sea Ice & - & DAMOCLES, & PolarView, DAMOCLES \\
\hline
\end{tabular}

Table 5. Ocean mission placed in context of international cooperation with respect to specific aspects of mission planning, science agenda and data product development and dissemination

\subsection{Sea Surface Temperature}

International operational and scientific cooperation formed the core of GHRSST activities that use data form ENVISAT AATSR, NOAA AVHRR, MSG SEVIRI, (Spinning Enhanced Visible and Infrared Imager) GOES (Geostationary Operational
Evironmental Satellite), MT-SAT (Multifunctional Transport Satellites), TRMM-TMI (Tropical Rainfall Measuring Mission-Microwave Imager), and EoS AQUA AMSRE and MODIS. GHRSST conducted scientific research and developed a Regional/global task sharing framework (R/GTS) in which over $15 \mathrm{~Gb}$ of 
satellite SST data are shared each day involving ESA, NOAA, NASA, EUMETSAT and other agencies. An advanced data management framework including search and discovery metdata repositiories for all data holdings and long-term stewardship of all products has been implemented and operates in a sustained NRT (Near Real-Time) mode [15]. Many operational users at National Meteorlogical and Hydrological Services (NMHS's) make full use of GHRSST data products and services through the R/GTS system. GHRSST seamlessly provides access to both research and operational data products in NRT, using a common open-standard data format supported by operational data centres so that users are freed from the burden of maintaining complex ingest code libraries. GHRSST data providers also deliver an uncertainty estimate with every SST measurement within every product. The formation of a CEOS Virtual Constellation of SST is under discussion to embed the GHRSST activities in CEOS contributions for the GEOSSS. The primary role of the SST-VC will be to assist GHRSST in maintaining the GHRSST Data Processing Specifications (GDS) used by contributing Agencies, to assist CEOS members in becoming part of the GHRSST activity and to help the GHRSST R/GTS implementation become more efficient.

\subsection{Ocean Dynamic Topography}

The joint NOAA/NASA/EUMETSAT/CNES Ocean Surface Topography Science Team (OST ST) supports basic research and investigations associated with joint satellite altimetry missions, including TOPEX/Poseidon (T/P), Jason-1, Jason-2 and other ocean altimetry missions. The objective of the OST-ST, which is a continuation of the T/P, Jason-1 science teams, are to 1) provide the scientific underpinning for production of the best possible satellite-derived ocean and continental water surface topography data 2) to demonstrate the Earth science and applications based on analyses and use of these data and 3) to evaluate operational use of ocean and continental surface topography data.

The objective of the Ocean Surface Topography Virtual Constellation (OST VC) is to implement a sustained, systematic capability to observe the surface topography of the global oceans for the coming decades. Already in 1992, the so-called "Purple Book" by Koblinsky et al [26] established the concept of a space-based ocean circulation observing system including a high-altitude, low-inclination mission carrying a high-precision altimeter package (the reference mission) on a non-sunsynchronous, repeat orbit, for the determination of large-scale ocean currents, complemented polar-orbiting missions carrying precision altimeters and additional capabilities (e.g. GMES Sentinel-3 operating in a SAR mode) providing an extended temporal and spatial sampling providing information on the mesoscale eddies. A prolongation of this approach was subscribed in the Venice meeting and a dedicated OST VC meeting In Assmannshausen 2008. A user requirement document for the constellation has been set up to support shaping the future along these lines [27].

On the operational cooperation level, Jason-2 is a nice example of an enhanced operational cooperation where NOAA and EUMETSAT provide the NRT data products, CNES, and NASA the 'offline' (delayed, higher precision) ones.

\subsection{Ocean Surface Winds}

Several science teams and groups are in place to support the missions. The key example is NASA Ocean Vector Wind Science Team in support of the SeaWinds missions. An International Ocean Vector Wind Science Team is currently being established joining these sciences teams to enhance international collaboration and to aid in the calibration and validation of new missions. Bourrassa et al. [17] stressed that the set spatial and temporal sampling goals cannot be achieved with a single satellite in low earth orbit. Freely shared, easy accessible data and constellation thinking are warranted and the OVW Virtual Constellation has been agreed by the CEOS to take care. The OVW VC has currently a focus on improvements in marine warnings and forecasts over the global oceans to the protection of lives and property both on the high seas and along coastal areas. The OVW VC also considers significant wave height from satellite altimetry, already being provided by the Ocean Surface Topography Constellation (see Sect. 3.2), to facilitate easy access to NRT products highly relevant for marine safety.

A strong transatlantic operational cooperation is implemented in the (IJPS) of NOAA and EUMETSAT sharing available processors and cooperating on training and capability building.

\subsection{Ocean Colour}

The International Ocean-Colour Coordinating Group (IOCCG) was established in 1996 as an international Committee of experts to develop global consensus and synthesis concerning satellite ocean colour. In due course, specialised scientific working groups are set up to investigate various aspects of ocean-colour technology The IOCCG plays also a strong role in capacity building and supports advanced training courses on applications of ocean-colour data in various countries. In 2008, the CEOS virtual constellation for ocean colour radiances (OCR-VC) has been established to further embed the work of the IOCCG within the CEOS programmatic cooperations. A particular purpose of the OCR-VC is to ensure a long-term, sustained record of calibrated measurements from multiple satellites that can be merged together to improve global 
ocean spatial coverage and to produce time series for coastal and open ocean waters of scientific data products related to marine ecosystems and ocean biogeochemistry.

\subsection{Ocean Surface Salinity}

There are science teams in place for missions like SMOS and Aquarius, but apart from some common members they currently formally unconnected. A CEOS Virtual Constellation for surface salinity is under discussion.

\subsection{Sea Ice}

Promotion of satellite sea ice product utilisation is basically done in user-producers programs like PolarView, www.polarview.org, or DAMOCLES (Developing Arctic Modeling and Observing Capabilities for Long-term Environmental Studies), www.damocles-eu.org. These programs do also foster a lot of science cooperation. The CliC (Climate and Cryosphere ) project has been established to stimulate, support, and coordinate research into the climate system aspects of the cryosphere as a whole. CliC is sponsored by the World Climate Research Programme, the Scientific Committee on Antarctic Research (SCAR), and the International Arctic Science Committee. Currently, there is neither a dedicated CEOS constellation regarding sea ice nor a dedicated multimission science team.

\section{DISCUSSION AND CONCLUSIONS}

In this paper, we have assessed the progress of transition towards sustainable and permanent operational satellite systems for key oceanographic variables that can be observed from space. We can restate the GODAE final symposium conclusion of Wilson et al. [22] that an impressive progress made over the last decade: Sea Surface Temperature and Ocean Surface Topography demonstrate communities, which are well integrated into the wider operational infrastructure. The challenge is to keep up the good work done and the work in progress. The same is the case for Ocean Vector Winds, but here an enhanced international scientific cooperation and coordination will help to advance in operational oceanography aspects, which then will bring an enhanced global utilisation.

The Ocean Colour community has several components in place to quickly follow up in transitioning. Several follow-on series of missions in a more operational setting are approved. Open data access is however still an issue for some. Access to raw data and calibration information is needed to accurately merge imagery from multiple missions to investigate long-term changes to ocean ecosystems and other impacts of human activities.
Ocean Salinity is a new community in satellite oceanography and therefore trailing with respect to transitioning into operations. It may catch up in the decade to come or if needed roughly in the decade hereafter.

In all the chains, the climate impetus will ask for continued support of the research agencies and climate research community to revisit and reprocess the operational series and their research predecessors.

Based on a qualitative assessment of Tab. 4 and 5 one could argue that indeed operational maturity is most advanced in those chains where the international cooperation and coordination is the most intense. It must however also be accepted that activities leading to new and better systems are successful when there is a genuine user need for better capability that has not been met by existing operational coordination mechanisms, The GHRSST product services grew 'bottom up' but are now used by many operational agencies.

With more nations arriving at the international arena and the ongoing demand for higher temporal and spatial resolution, it would be unwise dismiss the paths of cooperation. CEOS is a framework that works on a best effort basis but has a strong link to the overarching framework of the GEOSS. The CEOS virtual constellations are young, but early successes demonstrate that the synergetic advantages can clearly outweigh the bureaucratic burden involved. Constellations for the key ocean variables have to stay in close interplay with their science team counterparts and operational teams and need to keep focus on tasks that bring the communities forward. The CEOS constellation may serve as vehicles for cross community exchange and learning but should be specific and not overlap, duplicate or replace the role and activities of existing or new science teams.

Last but not least, perpetual user consultation and data usage support activities are essential, to keep the records of the requirements on the observing capability up to date, and to reach a full utilisation and return of the operational infrastructure for now and the future.

\section{REFERENCES}

1. Ratier, A. "Space-based observations in the Global Ocean Observing System: the operational transition issue", White Paper, OceanObs'99, San Raphael, France, 1999.

2. Bell, M. and Le Traon, P.-Y. (eds), Special Issue on the Revolution of Global Ocean Forecasting-GODAE: 10 Years of Achievement, Oceanography 22 (3), 14-225, 2009.

3. Donlon, C., Robinson, I., Casey, K., Vazquez, J., Armstrong, E., Arino, O., Gentemann, C., May, D., Le Borgne, P., Piollé, J.-F., Barton, I., Beggs, H., Poulter, D., Merchant, C., Bingham A., Heinz, S., Harris, A., Wick, G., Emery, W., Minnett, P., Evans, R., Llewellyn- 
Jones, D., Mutlow, C., Reynolds, R., Kawamura, H. and Rayner, N., The Global Ocean Data Assimilation Experiment (GODAE) High Resolution Sea Surface Temperature Pilot Project (GHRSST-PP), Bull. Am. Meteorol. Soc., 88 (8), 1197-1213, 2007. doi:10.1175/BAMS-88-8-1197.

4. GCOS Implementation Plan for the Global Observing System for Climate in Support of the UN Framework Convention on Climate Change, 2010 Update, GCOS 92, (WMO/TD No. 1219), pp. 153, 2009.

5. Le Traon, P., Bell, M., Dombrowsky, E., Schiller, A. and Wilmer Becker, K., (2010). "GODAE OceanView: From an Experiment Towards a Long-Term International Ocean Analysis and Forecasting Program" in these proceedings (Vol. 2), doi:10.5270/OceanObs09.cwp.57.

6. Bahurel, P. \& Co-Authors (2010). "Ocean Monitoring and Forecasting Core Services, The European MyOcean Example" in these proceedings (Vol. 1), doi:10.5270/OceanObs09.pp.02.

7. Brassington, G.B. \& Co-Authors (2010). "Short to MediumRange Ocean Forecasts: Delivery and Observational Requirements" in these proceedings (Vol. 1), doi:10.5270/OceanObs09.pp.08.

8. Eyre, J. \& Co-Authors (2010). "Requirements of Numerical Weather Prediction for Observations of the Oceans" in these proceedings (Vol. 2), doi:10.5270/OceanObs09.cwp.26.

9. Balmaseda, M. \& Co-Authors (2010). "Initialization for Seasonal and Decadal Forecasts" in these proceedings (Vol. 2), doi:10.5270/OceanObs09.cwp.02.

10. Hurrell, J. \& Co-Authors (2010). "Decadal Climate Prediction: Opportunities and Challenges" in these proceedings (Vol. 2), doi:10.5270/OceanObs09.cwp.45.

11. Fairall, C. \& Co-Authors (2010). "Observations to Quantify Air-Sea Fluxes and their Role in Climate Variability and Predictability" in these proceedings (Vol. 2), doi:10.5270/OceanObs09.cwp.27.

12 Gulev, S. \& Co-Authors (2010). "Surface Energy, CO2 Fluxes and Sea Ice" in these proceedings (Vol. 1), doi:10.5270/OceanObs09.pp.19.

13. Lee, T. \& Co-Authors (2010). "Ocean State Estimation for Climate Research" in these proceedings (Vol. 2), doi:10.5270/OceanObs09.cwp.55.

14. Nerem, R. \& Co-Authors (2010). "Observations of Sea Level Change: What Have We Learned and What Are the Remaining Challenges?" in these proceedings (Vol. 2), doi:10.5270/OceanObs09.cwp.65.

15. Donlon, C. \& Co-Authors (2010). "Successes and Challenges for the Modern Sea Surface Temperature Observing System" in these proceedings (Vol. 2), doi:10.5270/OceanObs09.cwp.24.

16. Wilson, S. \& Co-Authors (2010). "The Ocean Surface Topography Constellation: The Next 15 Years in Satellite Altimetry" in these proceedings (Vol. 2), doi:10.5270/OceanObs09.cwp.92.
17. Bourassa, M. \& Co-Authors (2010). "Remotely Sensed Winds and Wind Stresses for Marine Forecasting and Ocean Modeling" in these proceedings (Vol. 2), doi:10.5270/OceanObs09.cwp.08.

18. Yoder, J., Dowell, M., Hoepffner, N., Murakami, H. and Stuart, V., (2010). "The Ocean Colour Radiance Virtual Constellation (OCR-VC)." in these proceedings (Vol. 2), doi:10.5270/OceanObs09.cwp.96.

19. Lagerloef, G. \& Co-Authors (2010). "Resolving the Global Surface Salinity Field and Variations by Blending Satellite and In Situ Observations" in these proceedings (Vol. 2), doi:10.5270/OceanObs09.cwp.51.

20. Breivik, L. \& Co-Authors (2010). "Remote Sensing of Sea Ice" in these proceedings (Vol. 2), doi:10.5270/OceanObs09.cwp.11.

21. Swail, V. \& Co-Authors (2010). "Wave Measurements, Needs and Developments for the Next Decade" in these proceedings (Vol. 2), doi:10.5270/OceanObs09.cwp.87.

22. Wilson, S., Benveniste, J., Bonekamp, H., Donlon, C., Drinkwater, M., Fellous, J-L., Gohil, B.S., Jacobs, G., LeTraon, P-Y., Lindstrom, L., Lin, M., Nakagawa, K., and Parisot, F., "Satellite Observing Systems and Relevance to GODAE", GODAE Final Symposium, Nice, France, 2008. (http://www.godae.org/Invitedpapers.html)

23. Ward, S. (2008). The Earth Observation Handbook Climate Change Special Edition 2008, ESA SP-1315, ESA Communications Production Office, ESTEC, PO Box 299, 2200 AG Noordwijk, The Netherlands ISSN No.: 0379-6566, pp. 265.

24. Lindstrom, E. \& Co-Authors (2010). "Research Satellite Missions" in these proceedings (Vol. 1), doi:10.5270/OceanObs09.pp.28.

25. Drinkwater, M. \& Co-Authors (2010). "Status and Outlook for the Space Component of an Integrated Ocean Observing System" in these proceedings (Vol. 1), doi:10.5270/OceanObs09.pp.17.

26. Koblinsky, C., Gaspar, P. and Lagerloef, G. (eds). The Future of Spaceborne Altimetry - Oceans and Climate Change: A Long-Term Strategy. Joint Oceanographic Institutions, Inc., 85 pp, 1992.

27. Escudier, P. and Fellous, J. "The Next 15 Years of Satellite Altimetry: Ocean Surface Topography Constellation" User Requirements Document. CLS.DOS/NT/09.092, 47 pp, 2009. 